\title{
Comparison of Increased Knowledge and Existence of Larvae between Before and After Education in Primary School Guards in Mojokerto City
}

\author{
Anindita Abigail Faradina ${ }^{1}$, Sulistiawati ${ }^{2}$, Erwin Astha Triyono ${ }^{3}$
}

\author{
${ }^{1}$ Faculty of Medicine, Universitas Airlangga, Surabaya. \\ ${ }^{2}$ Department of Public Health and Preventive Medicine, Faculty of Medicine, Universitas Airlangga, Surabaya. \\ ${ }^{3}$ Department of Internal Medicine, Faculty of Medicine, Universitas Airlangga - Dr. Soetomo General Hospital, Surabaya.
}

\section{A B S T R A C T}

Introduction: Dengue fever is a tropical disease caused by Dengue virus that is still becoming one of the main health problems in Indonesia. Dengue fever patients are usually children with age ranging between 5-14 years old, that indicates a higher likelihood of infection at school compared to infection at home. The purpose of this study is to analyze the difference between knowledge and practice of DHF prevention and also the existence of larvae before and after education to the elementary school's guard in Mojokerto

Methods: The research method used in this study is a pre-experimental design method, which is a one group pretest and postteststudy. The number of samples was 25 school guards from all elementary school in the urban villages with DHF cases in 2017.

Results: The average correct answer at pretest was $58.9 \%$ while in posttest it was $80.9 \%$. From the results of the Wilcoxon test also obtained p-value $0.00(<0.05)$. From observation before the education, one school was found positivewith larvae, and after the education was given, all schools were found negative.

Conclusion: There are differences in knowledge and practice prevention of dengue fever between before and after education in primary school guards in Mojokerto.

\section{*Correspondence: sulistiawati@fk.unair}

JUXTA: Jurnal IImiah Mahasiswa Kedokteran Universitas Airlangga

p-ISSN: 1907-3623; e-ISSN: 2684-9453

DOI: 10.20473/juxta.V10I12019.11-14

Open access under Creative Commons Attribution-ShareAlike 4.0 International License (CC-BY-SA)

\section{ARTICLE INFO}

Article history:

Received 26 December 2018

Received in revised form 22 January 2019

Accepted 23 January 2019

\section{Keywords:}

Intestinal protozoa infections, Nutritional status,

Blastocystis hominis, Giardia lamblia. 


\section{Introduction}

DHF or Dengue Hemorrhagic Fever is one of the tropical and subtropical diseases caused by the dengue virus and transmitted through mosquito vectors, mainly Aedes aegypti. The first epidemic of dengue cases was reported to occur in Manila, Philippines in 1953 which then spread to Southeast Asia 2 decades later and is still one of the major infectious diseases in the world. The incidence of this disease in the world continues to increase over the past few decades. Three WHO member countries reported an increase in cases of dengue fever in the world, which amounted to 2.2 million cases in 2010 and increased to 3.2 million cases in 2015. In 2016, they were still considered to have very high DHF cases, as evidenced by more than 2.38 million cases only from the United States, Brazil also reported an increase in cases up to three times compared to $2014^{1}$

In Indonesia, DHF is still one of the main problems of community health even though control efforts have been made. It was recorded that there were 100,347 cases of dengue fever in 2014 and increased to 126,675 cases in 2015 spread in 34 provinces in Indonesia ${ }^{2}$. The Head of the East Java Health Office also said that in 2015 there were Extraordinary Events (KLB) in 27 Kab / Kota in East Java, an increase in the number of sufferers in $10 \mathrm{Kab} / \mathrm{Kota}$, and an increase in mortality in $25 \mathrm{Kab} / \mathrm{Kota}$, one of which was Kota Mojokerto ${ }^{3}$.

The city of Mojokerto itself has a population of 126,404 in 2017. In the same year, Mojokerto received reports of 65 cases resembling dengue fever, and 11 of them were positive for dengue hemorrhagic fever. This incident occurred in 6 out of a total of 18 urban villages in Mojokerto City, namely in the Gedongan, Balongsari, Meri, Wates, Miji, and Prajurit Kulon.

From the data released by the Indonesian Ministry of Health regarding Dengue Hemorrhagic Fever sufferers, the highest proportion is in school-age children, especially the $5-14$ year age group with $42.72 \%^{2}$. This shows that there is a higher chance of infection in school compared to infection at home.

So far, many studies have been conducted on education and training for students and the public about knowledge and ways to prevent dengue. But no one has focused on educating school guards as the person most responsible for school hygiene and sanitation. Empowerment of school guards in larva monitoring is expected to reduce the number of infections in children in school. Therefore the researcher wanted to know the comparison of knowledge and existence of larvae between before and after the education of primary school guards in the Municipality of Mojokerto as an effort to prevent dengue infection in schools.

\section{Methods}

This research was a pre-experimental design method, which is a one group pretest and posttest study. The variables were education about dengue haemorrhagic fever and its prevention, while the other variable were knowledge of Primary School guards about DHF and its prevention. The population was total sampling from all elementary school guards in the urban villages with DHF cases in 2017, and had received approval of ethical clearance from ethics commission of Faculty of Medicine Universitas Airlangga. The research data are primary data obtained by using questionnaires in the form of pretest and posttest given to the school guards. And also through the results of larva surveys in elementary schools one week before and after given the education about DHF and ways to prevent it. The education was given with the lecture method, and participants were also given booklets. Data analysis uses the help of SPSS software. The data obtained will be analysed and presented in the form of table.

\section{Results}

Table 1. The characteristics of subjects.

\begin{tabular}{ccc}
\hline & & $\mathbf{n}=\mathbf{2 5}$ \\
\hline Age & & \\
& $21-30$ & $3(12 \%)$ \\
& $31-40$ & $7(28 \%)$ \\
& $41-50$ & $8(32 \%)$ \\
& $>50$ & $7(28 \%)$ \\
Sex & & \\
& Male & $25(100 \%)$ \\
& Female & $0(0 \%)$
\end{tabular}

Level of education

$\begin{array}{lc}\text { SD } & 1(4 \%) \\ \text { SMP } & 7(28 \%) \\ \text { SMA } & 17(68 \%)\end{array}$

The results of this study revealed that from 25 school guards, all respondents are male $(100 \%)$, the majority of age is $41-50$ years old $(32 \%)$, and the majority of the their education level is SMA or high school $(68 \%)$.

Table 2. Number of Pretest and Posttest Correct Answers

\begin{tabular}{cccc}
\hline No. & $\begin{array}{c}\text { Number of } \\
\text { correct answers }\end{array}$ & Pretest & Posttest \\
\hline 1. & $0-4$ & $1(4 \%)$ & $2(8 \%)$ \\
2. & $5-9$ & $18(72 \%)$ & $3(12 \%)$ \\
3. & $10-14$ & $6(24 \%)$ & $20(80 \%)$ \\
\hline & Total & $25(100 \%)$ & $25(100 \%)$ \\
\hline
\end{tabular}

The results of this study shows the total correct answers at the pretest and posttest that have been done by the respondents. At the pretest, the highest frequency of the total correct answers was a group of total 5-9 correct answers $(72 \%)$. Whereas in the posttest, the highest frequency was found in the total correct answer group between 10-14 (80\%).

Table 3. Kolmogorov-Smirnov normality test

\begin{tabular}{cccc}
\hline No. & Group & sig & Conclusion \\
\hline 1. & Pretest & 0.173 & Normal \\
2. & Posttest & 0.003 & Abnormal \\
\hline
\end{tabular}


Based on the table above, it can be seen that pretest data has a value of $p>0.05$ which can be concluded that the data group is normally distributed. Whereas in the posttest data, the value of $p<0.05$ means that the data is not normally distributed.

Table 4. Wilcoxon test for pretest and posttest

\begin{tabular}{ccccc}
\hline Level of knowledge & $\mathrm{N}$ & Decrease & Fix & Increase \\
\hline Pretest - Posttest & 25 & 3 & 3 & 19 \\
$p$ Value & \multicolumn{3}{c}{$0,00(<0,05)$} \\
\hline
\end{tabular}

Based on the tabel above, we obtained a comparison of knowledge before education and after education, there were 19 respondents with improved results, 3 with fixed results, and 3 respondents with decreased results. It also shows that the Wilcoxon p-value test is smaller $\alpha(0.05)$ so it can be concluded that there is a difference in DHF knowledge in primary school guards between before (pretest) and after (posttest) education.

Table 5. DHF Prevention Practices by Looking at Larvae Before and After Education

\begin{tabular}{ccc}
\hline Larvae exmination & Larvae + & Larvae - \\
\hline Before education & $1 / 4 \%$ & $24 / 96 \%$ \\
After education & $-/ 0 \%$ & $25 / 100 \%$ \\
\hline
\end{tabular}

The researcher examined all water shelters in each school, a week before and after the education of elementary school guards. Before the education was conducted, it was found that there was one elementary school that found positive larvae, while the other 24 schools or equal to $96 \%$ of the total samples were negative. While on examination a week after the education, all 25 schools $(100 \%)$ are found negative.

Table 6. Correlation Between Age and Posttest Total Correct Answers

\begin{tabular}{cccc}
\hline & \multicolumn{3}{c}{ Posttest } \\
\cline { 2 - 4 } Age & $\mathbf{0 - 4}$ & $\mathbf{5 - 9}$ & $\mathbf{1 0 - 1 4}$ \\
\hline $\mathbf{2 1 - 3 0}$ & - & - & 3 \\
$\mathbf{3 1 - 4 0}$ & - & 1 & 6 \\
$\mathbf{4 1 - 5 0}$ & 1 & 1 & 6 \\
$\mathbf{> 5 0}$ & - & 2 & 5 \\
\hline Total & 1 & 4 & 20 \\
\hline p-value Chi- & & 0,725 & \\
square & & &
\end{tabular}

In the Pearson Chi Square table above, the Asimp. Sig value is 0.725 . This can be interpreted that the age of the respondents did not have a correlation with the result of the posttest.

Table 7. Correlation Between Level of Education and Posttest Total Correct Answers

\begin{tabular}{cccc}
\hline Level of & \multicolumn{3}{c}{ Posttest } \\
\cline { 2 - 4 } Education & $\mathbf{0 - 4}$ & $\mathbf{5 - 9}$ & $\mathbf{1 0 - 1 4}$ \\
\hline SD & - & 1 & - \\
SMP & - & 1 & 6 \\
SMA & 1 & 2 & 14 \\
\hline Total & 1 & 4 & 20 \\
\hline
\end{tabular}

p-value
Chi-square

In the Pearson Chi Square table above, the Asimp. Sig value is 0.205 . This can be interpreted that the level of educationn of the respondents did not have a correlation with the result of the posttest.

\section{Discussion}

Mojokerto City which is \pm 22 meters above sea level, and has the slope about $0 \%-3 \%$ is a relatively flat land surface which can trigger the slow flow of rivers or waterways. It can speed up the siltation and trigger the emergence of many puddles in various places when the rain arrives. High DHF distribution is also related with Indonesia's geographical condition which is a tropical climate with year-round rain that causes dengue vectors to easily multiply. Rain will cause an increase in air humidity which has an impact on increasing mosquito breeding spots.In addition, high population is also one of the biggest factors supporting the high incidence of DHF, because the more high populated an area, the easier it is for Aedes mosquitoes to spread the Dengue virus from one person to another. A study in Yogyakarta found similar result, that there is a positive and significant relationship between the incidence rates of dengue hemorrhagic fever and regional high population ${ }^{4}$.

In this study the form of education used was the lecture method, namely an educational or teaching method that was carried out by conveying information and knowledge verbally, which was generally followed passively ${ }^{5}$. In addition, to improve the effectiveness of communication and interaction, educational media in the form of slides and pamphlets were chosen. The level of effectiveness of the lecture method has a great effect on increasing the knowledge of mothers in handling diarrhea ${ }^{6}$.

Media in the form of modules are also given in the hope of helping the respondents to apply the knowledge that has been obtained in everyday life in their environment. Training using modules can improve the knowledge, attitudes and practices of respondents ${ }^{7}$. Based on another study, there is an influence of the use of pocket books on aspects of mother's knowledge and skills ${ }^{8}$.

From the Wilcoxon test, the $p$-value is smaller than $\alpha$ (0.05) which is 0,00013 so that it can be concluded that there is a significant change in DHF knowledge in primary school guards between before (pretest) and after (posttest) education. In another study it was stated that educational programs proved effective as a method to increase knowledge and attitudes towards breastfeeding or breastfeeding ${ }^{9}$. Another study also fond a similar result, that health education was statistically influential in increasing knowledge $^{10}$.

From larvae observations after education, all schools were found negative. According to other studies it can be seen that DHF control interventions through health promotion or education in community groups accompanied by larvasidation contribute to decreasing larvae density more than the non-intervention group, although the decline 
has not been to the level expected by vector control programs ${ }^{11}$. This is also in line with another study that state, community empowerment research accompanied by health promotion and environmental management that have a positive impact on the decline in larvae indexes in Brazil ${ }^{12}$.

From the results of the Chi Square test conducted to determine whether there is a relationship between age and the total correct posttest answers, the Asimp. Sig value is 0.725 . Because the value of Asimp. Sig 0.725>0.05, it can be concluded that there is no significant relationship between age and posttest results. This is similar with another study which suggested that not all younger people have lower knowledge as well as vice versa older people do not necessarily have a higher level of knowledge ${ }^{13}$. This can happen because in addition to age, the level of knowledge of a person can also be influenced by several other factors such as the level of education and employment ${ }^{14}$.

From the results of the Chi Square test, the Asimp. Sig value is 0.205 . Because the value of Asimp. Sig 0.205> 0.05 , it can be concluded that there is no significant relationship between the level of education and the results of the posttest. This is not in line with another study which showed that participants who had high school education or higher, got the right answer with a higher frequency compared to participants who had the last education lower than high school. In addition participants with higher levels of education also have more attitudes and practices that support DHF control, including not storing water in containers, attending community meetings, also educating family members and neighbors about DHF prevention measures ${ }^{15}$. The research is also similar with another study that stated,the level of knowledge influenced by education, for higher levels of education, the level of knowledge was also better ${ }^{16}$.

\section{Conclusion}

There are differences in knowledge of DHF prevention and existence of larva in water shelters before and after education to the elementary school's guards in Mojokerto.

\section{CONFLICT OF INTEREST}

The author stated there is no conflict of interest.

\section{REFERENCES}

1. WHO. Dengue and Severe Dengue. 2018.

2. Penderita DBD Tertinggi pada Anak Sekolah. Kementrian Kesehatan. 2016.

3. Januari-Juni, Kasus DBD di Jatim Meningkat Dinas Komunikasi dan Informatika Provinsi Jawa Timur. 2015.
4. Riyanto S. Hubungan Kepadatan Penduduk dengan Kejadian Demam Berdarah Dengue di Kabupaten Sleman. Department of Medical Education. Universitas Muhammadiyah Yogyakarta, 2017.

5. Syah M, Wardan AS, Rakhmat MF and Muchlis. Psikologi Pendidikan. Bandung: PT Remaja Rosdakarya., 1995.

6. Yunita L. Efektifitas Pendidikan Kesehatan dengan Metode Ceramah terhadap Tingkat Pengetahuan Ibu dalam Penanganan Diare Balita di Sekitar UPT TPA Cipayung, Depok. Program Studi IImu Keperawatan. Jakarta: Universitas Islam Negeri Syarif Hidayatullah, 2016

7. Jumiyati n, A NS and Margawati A. Pengaruh Modul terhadap Peningkatan Pengetahuan, Sikap dan Praktek Kader dalam Upaya Pemberian ASI Eksklusif. Gizi Indonesia. 2014: 19-28.

8. Rahmawati NI, Nugraheni SA and Mawarni A. Pengaruh Penggunaan Buku Saku oleh Motivator terhadap Pengetahuan dan Ketrampilan Motivator dalam Mengatasi Permasalahan Pemberian ASI (di Kecamatan Sewon Kabupaten Bantul). Jurnal Ners dan Kebidanan Indonesia. 2015; 3.

9. Hernandez Perez MC, Diaz-Gomez NM, Romero Manzano AM, Diaz Gomez JM, Rodriguez Perez V and Jimenez Sosa A. Effectiveness of An Intervention to Improve Breastfeeding Knowledge and Attitudes among Adolescents. Revista Espanola de Salud Publica. 2018; 92.

10. Salaudeen A, Musa $O$, Akande $T$ and Bolarinwa $O$. Effects of Health Education on Cigarette Smoking Habits of Young Adults in Tertiary Institutions in a Northern Nigerian State. Health Science Journal. 2011; 5.

11. Sitorus $H$, Taviv $Y$, Budiyanto A, Ambarita LP, Salim M and Mayasari R. Perbandingan Indeks Larva Vektor Demam Berdarah Dengue Pra dan Paska-Intervensi di Kota Prabumulih. Balaba: Jurnal Litbang Pengendalian Penyakit Bersumber Binatang Banjarnegara; Vol 13, No 1 Juni (2017). 2017.

12. Caprara A, Lima JW, Peixoto AC, et al. Entomological Impact and Social Participation in Dengue Control: A Cluster Randomized Trial in Fortaleza, Brazil. Transactions of the Royal Society of Tropical Medicine and Hygiene. 2015; 109: 99-105.

13. Hanifah M. Hubungan Usia Dan Tingkat Pendidikan dengan Pengetahuan Wanita Usia 20-50 Tahun tentang Periksa Payudara Sendiri (SADARI). Program Studi Pendidikan Dokter. Jakarta: Universitas Islam Negerei Syarif Hidayatullah, 2010.

14. Nursalam. Konsep Penerapan Metodologi Penelitian IImu Keperawatan. Jakarta: Salemba Medika, 2001.

15. Diaz-Quijano FA, Martinez-Vega RA, RodriguezMorales AJ, Rojas-Calero RA, Luna-Gonzalez ML and Diaz-Quijano RG. Association between the Level of Education and Knowledge, Attitudes and Practices Regarding Dengue in the Caribbean Region of Colombia. BMC Public Health. 2018; 18: 143

16. Purwati W. Tingkat Pengetahuan Tentang Kesehatan Gigi dan Mulut Guru Penjaskes SD di Kecamatan Rendang Tahun 2013. 2013. 